\title{
Farm Level Technical Efficiency of Paddy Production in Andhra Pradesh: An Empirical Evidence from the Cost of Cultivation Survey Data
}

\author{
K.S.R. Paul, ${ }^{\text {", G.P. Sunandini' }}$, Shakuntala Irugu ${ }^{3}$ and K. Suhasini ${ }^{4}$ \\ ${ }^{1}$ Senior scientist, Cost of Cultivation Scheme, Agricultural College, Bapatla, Professor Jayashankar Telangana State Agricultural \\ University, Andhra Pradesh, India \\ ${ }^{2}$ Principal Scientist \& Field Officer, Department of Agricultural Economics, College of Agriculture, Professor Jayashankar Telangana \\ State Agricultural University, Hyderabad, Telangana, India \\ ${ }^{3}$ Scientist, Cost of Cultivation Scheme, Regional Agricultural Research Station, Palem, Professor Jayashankar Telangana State \\ Agricultural University, Nagarkurnool, Telangana, India \\ ${ }^{4}$ Professor, Univ. Head\& Associate Dean, Department of Agricultural Economics, Professor Jayashankar Telangana State Agricultural \\ University, Hyderabad, Telangana, India
}

*Corresponding author: ksolmonrajupaul@gmail.com (ORCID ID: 0000-0001-7300-1213)

Received: $12-08-2020$

Revised: $14-11-2020$

Accepted: 03-12-2020

\begin{abstract}
The study calculated technical efficiency, Data Envelopment Analysis technique was employed, one of the non-parametric linear programing techniques to estimate the farm level technical efficiency of paddy production in Andhra Pradesh. This secondary data set contained 541 paddy producing farms/units across Andhra Pradesh state under five agro climatic zones viz North coastal, Godavari, Krishna, Southern and Scarce rainfall zones was studied. The results showed that the overall technical efficiency of the entire sample is 86.8 per cent inferring that about 13 per cent of the potential paddy yield is lost because of technical inefficiency in Andhra Pradesh. The yield gap was found to be $981.10 \mathrm{~kg} / \mathrm{ha}$ in Godavari zone and a minimum yield gap of $335 \mathrm{~kg} / \mathrm{ha}$ in North coastal zone with an average yield gap of $663 \mathrm{~kg} /$ ha for Andhra Pradesh indicating domestic paddy production could be significantly increased only by improving farmers practices with the current amount of resource they are using. The study suggested that there should be exposure to the improved technologies, frequent trainings and experience sharing mechanisms with efficient resource management practices.
\end{abstract}

Highlights

0 The marginal farms are found to be more technically efficient because even if limited amount of inputs they apply with personal care using family labour

Keywords: Data Envelopment Analysis, paddy production, technical efficiency, non-parametric method

Paddy is the widely consumed staple food for a large part of the world's human population, especially in Asia. Rice is one of the three major crops in the world among maize and wheat. Paddy is grown in an area of $43.79 \mathrm{M}$ ha with a production and productivity of $112.75 \mathrm{M} \mathrm{t}$ and $2576 \mathrm{~kg}$ ha-1 respectively in India (Agricultural statistics at a glance 2018). As per USDA report the global production of rice in 2019-20 is 115 Million metric tonnes after China 146 Million metric tonnes as compared to 2018-19 it was 115.63 in India and 148.5 in China. According to this report (Table 1) it is clear that the production in China and India

How to cite this article: Paul, K.S.R., Sunandini, G.P., Irugu, S. and Suhasini, K. (2020). Farm Level Technical Efficiency of Paddy Production in Andhra Pradesh: An Empirical Evidence from the Cost of Cultivation Survey Data. Economic Affairs, 65(4): 659-663.

Source of Support: None; Conflict of Interest: None 
is has declined. (Paddy Outlook, July 2019) when considered the production and productivity over the years there is a lot of fluctuations for the past decade as shown in the Table 2. In Andhra Pradesh, paddy is grown in an area of $2.18 \mathrm{M}$ ha with production of $126.91 \mathrm{M} \mathrm{t}$ and productivity of $5722 \mathrm{~kg} \mathrm{ha}^{-1}$ respectively (Agricultural statistics at a glance 2018), (Singh et al. 2020).

Table 1: Major Rice Producing Countries in the World Production in million metric tons

\begin{tabular}{lllll}
\hline Country & $\mathbf{2 0 1 8 - 1 9}$ & Per cent & $\mathbf{2 0 1 9 - 2 0}$ & Per cent \\
\hline USA & 7.12 & 1.71 & 6.29 & 1.51 \\
India & 115.63 & 27.70 & 115 & 27.68 \\
Pakistan & 7.4 & 1.77 & 7.5 & 1.81 \\
Thailand & 20.72 & 4.96 & 20.9 & 5.03 \\
Vietnam & 27.71 & 6.64 & 28 & 6.74 \\
Brazil & 7.34 & 1.76 & 7.34 & 1.77 \\
European Union & 1.98 & 0.47 & 2.04 & 0.49 \\
Indonesia & 37.1 & 8.89 & 37.4 & 9.00 \\
Nigeria & 4.7 & 1.13 & 4.9 & 1.18 \\
Philippines & 11.8 & 2.83 & 12.2 & 2.94 \\
Burma & 13.18 & 3.16 & 13.3 & 3.20 \\
China & 148.5 & 35.57 & 146 & 35.14 \\
Egypt & 2.8 & 0.67 & 3.05 & 0.73 \\
Japan & 7.65 & 1.83 & 7.7 & 1.85 \\
South Korea & 3.87 & 0.93 & 3.88 & 0.93 \\
Total & 417.5 & 100.00 & 415.5 & 100.00 \\
\hline
\end{tabular}

Source: www.usda.gov, pjtsau.edu.in.

Efficiency in production is a can be increased by using good technology along with better management of resources, available at the farmer s disposal. To increase the productivity the resources/ inputs have to be efficiently used which otherwise leads to inefficiency/ inability to produce maximum possible output even if the given level of inputs is made available. The present study was taken up with an objective to calculate the farm level technical efficiency and yield gap of paddy production in Andhra Pradesh technical.

\section{MATERIALS AND METHODS}

The required farm level data is obtained from 'the comprehensive scheme for cost of cultivation of principal crops funded by the Directorate of Economics \& Statistics (DES), Ministry of Agriculture, Govt. of India. This secondary data set contained 541 paddy producing farms/units across Andhra Pradesh state under five agro climatic zones viz North coastal, Godavari, Krishna, Southern and Scarce rainfall zones. The study used the latest available data for the year 2016-17 with an objective to calculate the technical efficiency and yield gap. For calculating technical efficiency Data Envelopment Analysis technique was employed.

\section{TOOLS USED FOR ANALYSIS}

\section{Data Envelopment Analysis (DEA) approach}

Efficiency is the key to understand the use of factor inputs for the production of particular product. There are many statistical techniques to calculate the efficiency of a production unit. Data Envelopment Analysis is one of the non-parametric linear programing techniques which creates a frontier with the score ranging between zero and one. The efficient firms are those which produce more output with same levels of inputs or same output with less inputs. This paper has used the

Table 2: Season-wise Area, Production and Productivity of Rice in India

\begin{tabular}{llllllllll}
\hline \multirow{2}{*}{ Year } & \multicolumn{2}{c}{ Area (In` 000 Ha) } & \multicolumn{3}{c}{ Production (In ‘ 000 Tonne) } & \multicolumn{3}{c}{ Productivity (In Kg./Ha) } \\
\cline { 2 - 9 } & Kharif & Rabi & Total & Kharif & Rabi & Total & Kharif & Rabi & Total \\
\hline $2010-2011$ & 38018 & 4845 & 42862 & 80607 & 15363 & 95970 & 2120 & 3171 & 2239 \\
$2011-2012$ & 40123 & 3883 & 44006 & 92738 & 12563 & 105301 & 2311 & 3235 & 2393 \\
$2012-2013$ & 38914 & 3840 & 42754 & 92368 & 12873 & 105241 & 2374 & 3353 & 2462 \\
$2013-2014$ & 39449 & 4687 & 44136 & 91497 & 15149 & 106646 & 2319 & 3232 & 2416 \\
$2014-2015$ & 39828 & 4282 & 44110 & 91391 & 14091 & 105482 & 2295 & 3291 & 2391 \\
$2015-2016$ & 39656 & 3843 & 43499 & 91413 & 12995 & 104408 & 2305 & 3382 & 2400 \\
$2016-2017$ & 39846 & 4148 & 43993 & 96303 & 13396 & 109698 & 2417 & 3230 & 2494 \\
$2017-2018$ & 39349 & 4425 & 43774 & 97135 & 15622 & 112758 & 2469 & 3531 & 2576 \\
$2018-2019$ & 39964 & 4192 & 44156 & 102040 & 14438 & 116478 & 2553 & 3444 & 2638 \\
\hline
\end{tabular}

Source: Ministry of Agriculture E Farmers Welfare, Govt. of India. (ON2374) E Past Issues. 
DEA technique to find out the efficiency of firms in comparison of those farms which have the least input output ratio. The most efficient firm has the score one and the most inefficient firm will have the score zero (Mousavi-Avval et al. 2011). The aim is to have optimized output level for the farmers by analyzing the performance data so that the best score is chosen. The inputs taken are family labour hours, casual labour hours, bullock/machine work hours, seeds, manure and fertilizers and the yield is taken as the output.

Each farm is considered as the Decision-making Unit (DMU) and there are $K$ farmers who are using $N$ inputs to produce $M$ outputs. Inputs are indicated by $x j k(j=1,2, \ldots \ldots, n)$ and the outputs are denoted by $Y i k(i=1,2, \ldots \ldots . ., m)$ for each farmer $k$ $(k=1,2, \ldots \ldots \ldots, K)$. The aim is to find the technical efficiency (TE) of the farmers using the method as specified by Coelli (1998), Worthington (1999), Coelli and Battese (1996), Battese, and Coelli (1995) which is represented by the following equation (Singh et al. 2019),

$$
T E_{k}=\sum_{i=1}^{m i y i k} / \sum_{j=1} v j x j k
$$

where, Yik is the amount of the $i^{\text {th }}$ output produced by the $k^{\text {th }}$ farmer. $x j k$ is the quantity of $j^{\text {th }}$ input used by the $k^{\text {th }}$ farmer. $u i$ and $v j$ are the output and input weights respectively. The farmer maximizes the technical efficiency, TEk, subject to,

$$
T E_{k}=\sum_{i=1} \stackrel{m n}{m i y i k} / \sum_{j=1} v j x j k \leq 1
$$

Where, $u i$ and $v j \geq 0$

This equation shows that the weight assigned to inputs and output are positive and the technical efficiency score for a farmer cannot be more than one. The selection of weights is done in such a manner that technical efficiency of the farmer is optimized. To choose optimal weights the linear programming model given below has been taken

Min $\mathrm{TE}_{\mathrm{k}}$

Subject to,

$$
\sum_{i=1}^{m} u i y i k-y j k+w \geq 0
$$

where, $k=1,2, \ldots \ldots \ldots \ldots \ldots, K$

$$
\underset{j=1}{n j k-\Sigma u j x j k} \geq 0
$$

and $u i$ and $v j \geq 0$

The above mentioned model shows Technical Efficiency under constant returns to scale (CRS) with the assumption that if $w$ is equal to 0 it will lead to Technical Efficiency. If $w$ is unconstrained then it changes into variable returns to scale (VRS) and pure technical efficiency (PTE) is estimated. Technical Efficiency may be defined as the ratio of sum of the weighted outputs to sum of weighted inputs.

\section{Yield gap estimation}

Once the analysis of technical efficiency is done it is easy to find the level of potential yield of the crop for all the agro climatic zones of the state. In this study the zone wise yield gap for the paddy crop using formula as below has been estimated

Potential Yield = Existing Yield / Technical Efficiency

Yield gap $=$ Potential Yield - Existing yield

\section{RESULTS AND DISCUSSION}

\section{Estimation of resource use efficiencies}

Zone-wise technical efficiencies of paddy are presented in Table 3. Descriptive results of technical efficiency from the table showed that there is a variation in technical efficiency of paddy producers in Andhra Pradesh among the agro-climatic zones with a smallest and largest mean technical efficiency of $0.818(81.8 \%)$ and $0.883(88.7 \%)$ in scarce rainfall zone and Godavari zone, respectively. The overall technical efficiency of the whole sample is $86.8 \%$ implying that about $13 \%$ of the potential paddy yield is lost due to technical inefficiency in Andhra Pradesh (Singh, 2007), (Meenasulochani et al. 2018). The level of technical efficiency is directly related to the average paddy productivity in the agro climatic zones of Andhra Pradesh. Particularly in Andhra Pradesh the Godavari zone and krishna zone paddy farmers possess high managerial skills compared with other zones. Therefore, raising the proportion of farmers with high technical efficiency would have a great impact on increasing paddy production without incurring additional cost of production but adopting the best management 
Table 3: Technical efficiency in paddy of Andhra Pradesh

\begin{tabular}{llllllll}
\hline Sl. No. & Zone & $\begin{array}{l}\text { North } \\
\text { coastal Zone }\end{array}$ & $\begin{array}{l}\text { Godavari } \\
\text { Zone }\end{array}$ & $\begin{array}{l}\text { Krishna } \\
\text { Zone }\end{array}$ & $\begin{array}{l}\text { Southern } \\
\text { Zone }\end{array}$ & $\begin{array}{l}\text { Scarce } \\
\text { Rainfall Zone }\end{array}$ & $\begin{array}{l}\text { Andhra } \\
\text { Pradesh }\end{array}$ \\
\hline 1 & Technical Efficiency & 0.825 & 0.883 & 0.874 & 0.842 & 0.818 & 0.868 \\
\hline
\end{tabular}

Table 4: Farm-size wise technical efficiency of paddy growers in Andhra Pradesh

\begin{tabular}{llllll}
\hline Farm size & $\begin{array}{l}\text { Marginal } \\
\text { (less than 1ha) }\end{array}$ & $\begin{array}{l}\text { Small } \\
\mathbf{( 1 - 2 ~ h a ) ~}\end{array}$ & $\begin{array}{l}\text { Medium } \\
\mathbf{( 2 - 4} \text { ha) }\end{array}$ & $\begin{array}{l}\text { Semi-medium } \\
\mathbf{( 4 - 6 ~ h a )}\end{array}$ & $\begin{array}{l}\text { Large } \\
\text { (greater than 6 ha) }\end{array}$ \\
\hline Technical efficiency & 0.882 & 0.872 & 0.861 & 0.866 & 0.868 \\
\hline
\end{tabular}

Table 5: Average yield gap due to technical inefficiency of paddy growers in Andhra Pradesh in 2016-2017

\begin{tabular}{llllllll}
\hline S1. No. & Variable & $\begin{array}{l}\text { North coastal } \\
\text { Zone }\end{array}$ & $\begin{array}{l}\text { Godavari } \\
\text { Zone }\end{array}$ & $\begin{array}{l}\text { Krishna } \\
\text { Zone }\end{array}$ & $\begin{array}{l}\text { Southern } \\
\text { Zone }\end{array}$ & $\begin{array}{l}\text { Scarce Rainfall } \\
\text { Zone }\end{array}$ & $\begin{array}{l}\text { Andhra } \\
\text { Pradesh }\end{array}$ \\
\hline 1 & Existing Yield (Kg/ha) & 2504.71 & 6683.73 & 5553.09 & 4951.82 & 4553.15 & 4952.46 \\
2 & $\begin{array}{l}\text { Technical Efficiency } \\
\text { Potential Yield (Kg/ha) }\end{array}$ & 0.882 & 0.872 & 0.861 & 0.866 & 0.868 & 0.882 \\
& $\begin{array}{l}\text { (1/2) } \\
3\end{array}$ & 2839.81 & 7664.83 & 6449.58 & 5718.04 & 5245.56 & 5614.51 \\
& Yield Gap (Kg/ha) & & & & & & \\
4 & $(3-1)$ & 335.10 & 981.10 & 896.49 & 766.22 & 692.41 & 662.51 \\
\hline
\end{tabular}

practices in the agro climatic zone. This could be in effect through arranging exposure to the improved technologies, frequent trainings and experience sharing mechanisms also efficient resource management practices (Pradhan, 2018).

\section{Farm-size wise technical efficiency}

The technical efficiency varies according to farm size. Farm-size wise technical efficiency of paddy in Andhra Pradesh is presented in Table 4. The table shows that the marginal farms are found to be slightly more technically efficient than semi-medium and medium farms. This could be because even though they use very less amount of inputs they might apply them with personal care by themselves more efficiently since the usage of family labour is evidently more as the size of the farm decreases to reduce the out of pocket expenditure (Devi and Singh, 2014). However, farm sizes do not have a significant role in harnessing the potential of the paddy farms in Andhra Pradesh. Other measures to increase the technical efficiency are to be taken up across the farm sizes. But the contribution of family labour should be encouraged by medium, semimedium and large farmers (Bhatt, 2014) (Okello et al. 2019).

\section{Yield gap due to technical inefficiency}

The average yield gap between the potential and the actual yield is shown in Table 5. The table indicated that there is a maximum yield gap of $981.10 \mathrm{~kg} / \mathrm{ha}$ in Godavari zone and a minimum yield gap of $335 \mathrm{~kg} /$ ha in North coastal zone with an average yield gap of $663 \mathrm{~kg} / \mathrm{ha}$ for Andhra Pradesh (Jain et al. 2016).

This implies that there is a large yield gap that could be captured by raising the level of technical efficiency of paddy producers in Andhra Pradesh (Naveen and Paramasivam, 2019). This in turn helps the state to be efficient producer and increase the share of paddy production in the country. This will further help in increasing the exports.

\section{CONCLUSION}

The results indicated that the technical efficiency of paddy producers is about $0.87 \%$ for Andhra Pradesh but varies from Zone to Zone. The result shows that the average yield gap due to technical efficiency of farmers ranges from $335 \mathrm{~kg} / \mathrm{ha}$ (North Coastal Zone) to $981 \mathrm{~kg} / \mathrm{ha}$ (Godavari zone) with a yield gap of $663 \mathrm{~kg} / \mathrm{ha}$ for the Andhra Pradesh indicating paddy production in the state could be significantly increased by improving management practices of the farmers with the same amount 
of resources they are using. Capacity building on usage of appropriate scientific information to capture highest potential resource use efficiency with less cost, innovative methods to reduce the wastage and dissemination of all farm relevant knowledge material should be encouraged to make the technical efficiency more and more.

\section{REFERENCES}

Agricultural statistics at a glance. 2018. Directorate of Economics and Statistics, Department of Agriculture and Cooperation, Ministry of Agriculture, Government of India, New Delhi.

Agricultural statistics at a glance- Andhra Pradesh 2018. Directorate of Economics and Statistics. www.apdes. ap.gov.in.21.

Battese, G.E. and T.J. Coelli. 1995. A model for technical inefficiency effects in a stochastic frontier production function for panel data. Empirical Economics, 20: 325-332.

Bhatt, M.S. 2014. Technical efficiency and farm size productivity- micro level evidence from Jammu \& Kashmir. International. Journal of Food and Agricultural Economics, 2(4): 27-49.

Charnes, A., Cooper, W.W. and Rhodes, E. 1978. Measuring the efficiency of decision making units. European Journal of Operational Research, 2: 429-444.

Coelli, T.J. and Battese, G.E. 1996. Identification of factors which influence the technical inefficiency of Indian farmers. Australian Journal of Agricultural Economics, 40: 103-128.

Coelli, T. 1998. A Muti-stage methodology for solution of orientated DEA Models. Operation Research Letters, 23(35): 143-149.

Devi, L.G. and Singh, Y.C. 2014. Resource use and Technical Efficiency of Rice Production in Manipur. Economic Affairs, 59 Special Issue: 823-835.

Jain, R., Chauhan, S., Srivastava, S.K., Kingsley, I.T., Raju, S.S., Singh, J. and Kaur, A.P. 2016. Farm level technical efficiency for pulse production in India. Eco. Affairs, 61(3): 539-547.
Kumar, N.P. and Paramasivam, P. 2019. Technical Efficiency of Maize Production in Fluoride Affected Locales, Tamil Nadu: A Stochastic Frontier Approach. Eco. Affairs, 64(3): 633-642.

Ministry of Agriculture and Farmers Welfare. 2018. Season wise area, production and productivity of rice in India. http://www.indiaagristat.com.

Meenasulochani, R., Rajendran, T., Pushpa, J. and Senthilnathan, S. 2018. Technical Efficiency of Paddy Production and Factors Affecting the Efficiency in Nagapattinam District, Tamil Nadu. International Journal of Agriculture Innovations and Research, 6(6): 2319-1473.

Mousavi-Avval, Hashem, S. \& Shahin, R. and Ali, J. and Ali, M. 2011. Optimization of energy consumption for soybean production using Data Envelopment Analysis (DEA) approach. Applied Energy, 88(11): 3765-3772.

Okello, D.M., Wabbi, J.B. and Mugonola, B. 2019. Farm level allocative efficiency of rice production in Gulu and Amuru districts, Northern Uganda. Agric. Econ., 7: 19.

Pradhan, A.K. 2018. Measuring Technical Efficiency in Rice Productivity Using Data Envelopment Analysis: A Study of Odisha. International Journal of Rural Management, 14(1): $1-21$.

Samarpitha, A.N. Vasudev and Suhasini, K. 2016. Technical, economic and allocative efficiencies of rice farms in Nalgonda district of Telangana state. Eco. Affairs, 61(3): 365-374.

Singh, S. 2007. Technical Efficiency of Paddy Cultivation: A Socioeconomic Analysis of Haryana State. The IUP Journal of Agricultural Economics. IUP Publications 0(3): 36-47.

Singh, J., Dutta, T., Singh, J. and Singh, N. 2019. Farm Size and Technical Efficiency Relationship in Major CottonProducing States: Empirical Evidence from the Cost of Cultivation Survey Data. Restaurant Business, 118(11): 1314-1319.

Singh, V., Singh, V., Singh, S. et al. 2020. Effect of Zinc and Silicon on Growth and Yield of Aromatic Rice (Oryza sativa) in North-Western Plains of India. J. Rice Res. Dev., 3(1): 82-86.

Worthington, A.C. 1999. Measuring Technical efficiency in Australian Credit Unions. Manchester School, 67(2): 231248. 
